\section{JURNAL ABDIMAS

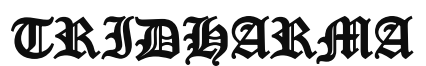

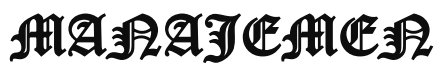

P-ISSN 2615-6849, E-ISSN 2716-070X

Jurnal ABDIMAS Vol. 2,No.3, Agustus 2021,Hal(54-61)

@ Prodi Manajemen Fakultas Ekonomi Universitas Pamulang

Email: abdimasjurnal.unpam@gmail.com Telp: (021) 741-2566

\title{
MENUMBUHKAN EKONOMI KREATIF KERAJINAN TANGAN PADA BAHAN LOAK TERHADAP SANTRI AL-KAMILAH DI MASA PANDEMI
}

\author{
Melvi Mulyana Sari, Rifia Ashfiyail Ulumiah, Aprillia Ervani, Maida Zerlina Octarisa, \\ Silviyani, Wiwik Hasbiyah AN.,S.H.I.,M.A \\ Dosen Dan Mahasiswa Prodi Akuntansi Fakultas Ekonomi Universitas Pamulang \\ Email: melvi.mulyana28@gmail.com, Rifiaashfiyail@ gmail.com, \\ aprilliaervani@gmail.com, maidazerlina002@gmail.com, viysilviyani04@gmail.com, \\ dosen00968@unpam.ac.id
}

\begin{abstract}
Abstrak
Tujuan dari Pengabdian kepada Masyarakat (PKM) ini adalah untuk mengetahui cara memanfaatkan bahan bekas sehingga menjadi barang yang bernilai tinggi dan bernilai jual secara kreatif di masa pandemi yang dilaksanakan di Yayasan Al-Kamilah yang berada di Sawangan Depok. Metode yang digunakan dalam PKM ini adalah dengan memberikan penyuluhan dan memberikan contoh bagaimana membuat kerajinan. Hasil dari pelaksanaan PKM ini, diharapkan kita dapat lebih memanfaatkan bahan bekas menjadi bahan yang bermanfaat pada masa pandemi.
\end{abstract}

Kata Kunci : Memanfaatkan bahan bekas, Pandemi Covid 19

Abstract

The purpose of this Community Service (PKM) is to find out how to use used materials so that they become goods of high value and creative value for sale during the pandemic which is carried out at the Al-Kamilah Foundation in Sawangan, Depok. The method used in this PKM is to provide counseling and provide examples of how to make crafts. The results of this PKM implementation, it is hoped that we can better utilize used materials to become useful materials during the pandemic.

Keywords: Utilizing used materials, Covid Pandemic 19

\section{PENDAHULUAN}

Indonesia dengan potensi kekayaan yang sangat besar baik potensi sumberdaya alam, keragaman budaya , maupun sumberdaya manusia, perlu mengedepankan kreatifitas dan inovasi dalam pembangunan nasional untuk mengoptimalkan berbagai potensi kekayaan yang dimiliki. Ekonomi kreatif yang berbasis kepada modal kreatifitas sumberdaya manusia, berpeluang mendorong daya saing bangsa Indonesia di masa depan. Jika sumber daya manusia Indonesia yang jumlahnya sangat besar memiliki kemampuan untuk berkreasi menciptakan inovasi dan nilai tambah, maka kreatifitas tersebut akan menjadi sumberdaya terbaru yang tidak ada habisnya. Kreatifitas akan mendorong dihasilkannya produk produk dari bahan yang sudah tidak terpakai menjadi produk yang bernilai tambah tinggi dan bermanfaat

Ekonomi kreatif adalah penciptaan nilai tambah yang berbasis ide yang lahir dari kreatifitas sumber daya manusia ( orang kreatif ) dan berbasis ilmu pengetahuan, termasuk warisan budaya dan teknologi. Dalam era perdagangan bebas, tantangan yang ada bukan hanya 


\section{JURNAL ABDIMAS

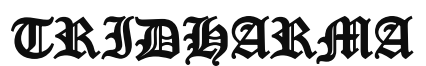

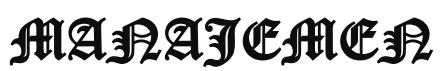

P-ISSN 2615-6849, E-ISSN 2716-070X

Jurnal ABDIMAS Vol. 2,No.3, Agustus 2021,Hal(54-61)

@Prodi Manajemen Fakultas Ekonomi Universitas Pamulang

Email: abdimasjurnal.unpam@gmail.com Telp: (021) 741-2566 untuk mempersiapkan sumber daya manusia (SDM) yang siap bekerja, melainkan juga harus mampu mempersiapkan dan membuka lapangan kerja baru. Realisasi yang terjadi di Indonesia ini, menghadirkan sebuah paradigma bahwa masyarakat Indonesia dididik untuk menjadi para pencari kerja. Dengan kondisi perekonomian yang tidak setabil, kemapanan dan keamanan dalam bekerja adalah tujuan utama, dan kemapanan tersebut didapat setelah menjadi karyawan yang mendapat gaji bulanan yang tetap. Sistem ekonomi kreatif diyakini mampu menjadi solusi dalam mengatasi masalah tersebut, sekaligus sebagai alternatif dalam menghadapi tantangan ekonomi global yang akan menggeser sistem ekonomi yang telah berjalan. Indonesia yang kaya akan budaya dan berpenduduk besar mempunyai potensi yang sangat besar dalam pengembangan ekonomi kreatif.

Pemanfaatan barang bekas yang sudah tidak terpakai yang bernilai seni dan juga mempunyai nilai guna merupakan terobosan baru dalam penanganan limbah sampah, dengan memanfaatkan bahan bekas atau bahan tidak terpakai menjadi suatu kerajinan tangan yang menarik dan bernilai ekonomis apalagi di masa pandemic seperti ini dan dapat menumbuh kembangkan kreatifitas masyarakat Indonesia.

\section{Metode Penelitian}

Berikut adalah beberapa paparan artikel yang digunakan. Tabel pertama merupakan judul dari masing masing artikel. Selanjutnya dari artikel yang kami dapat, kami lakukan pendalaman terhadap isi.

\begin{tabular}{|l|l|l|l|}
\hline $\begin{array}{l}\text { N } \\
\mathbf{o}\end{array}$ & Judul & Penulis & $\begin{array}{l}\text { Tahu } \\
\mathrm{n}\end{array}$ \\
\hline 1 & $\begin{array}{l}\text { Pengertian } \\
\text { Kerajinan } \\
\text { Tangan }\end{array}$ & $\begin{array}{l}\text { Sudita, } \\
\text { Ketut }\end{array}$ & 2014 \\
\hline
\end{tabular}

\begin{tabular}{|l|l|l|l|}
\hline 2 & $\begin{array}{l}\text { Pengembangan } \\
\text { ekonomi kreatif }\end{array}$ & $\begin{array}{l}\text { Pangestu } \\
\text {, Mari } \\
\text { Elka. }\end{array}$ & 2008 \\
\hline 3 & $\begin{array}{l}\text { Inovatif dan } \\
\text { Kreatif }\end{array}$ & $\begin{array}{l}\text { Nurseto, } \\
\text { Gandes, } \\
\text { Wahyu } \\
\text { Lestari, } \\
\text { and } \\
\text { Hartono } \\
\text { Hartono }\end{array}$ & 2015 \\
\hline 4 & $\begin{array}{l}\text { Hal - hal yang } \\
\text { perlu dilakukan } \\
\text { untuk menjadi } \\
\text { diri yang kreatif }\end{array}$ & $\begin{array}{l}\text { Diana, } \\
\text { R. } \\
\text { Rachmi. }\end{array}$ & 2006 \\
\hline 5 & $\begin{array}{l}\text { Cara untuk } \\
\text { mengembangka } \\
\text { n kreatifitas }\end{array}$ & $\begin{array}{l}\text { Putro, } \\
\text { Khamim } \\
\text { Zarkasih } \\
\text { Putro, } \\
\text { Khamim } \\
\text { Zarkasih }\end{array}$ & 2016 \\
\hline
\end{tabular}

Hasil dan Pembahasan

Berikut ini adalah penjabaran isi dari masingmasing artikel :

\begin{tabular}{|l|l|l|}
\hline $\begin{array}{l}\text { N } \\
\text { o }\end{array}$ & Judul & Pokok Bahasan \\
\hline 1 & $\begin{array}{l}\text { Pengertian } \\
\text { Kerajinan } \\
\text { Tangan }\end{array}$ & $\begin{array}{l}\text { Merupakan hal yang } \\
\text { berkaitan dengan } \\
\text { buatan tangan atau } \\
\text { kegiatan yang } \\
\text { berkaitan dengan } \\
\text { barang yang } \\
\text { dihasilkan melalui } \\
\text { keterampilan tangan } \\
\text { (kerajinan } \\
\text { tangan).Kerajinan } \\
\text { yang dibuat biasanya } \\
\text { terbuat dari berbagai } \\
\text { bahan.Dari kerajinan } \\
\text { ini menghasilkan } \\
\text { hiasan atau benda } \\
\text { seni maupun barang } \\
\text { pakai. Biasanya } \\
\text { istilah ini diterapkan } \\
\text { untuk cara tradisional } \\
\text { dalam membuat }\end{array}$ \\
\hline
\end{tabular}


JURNAL ABDIMAS

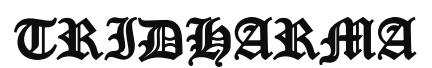

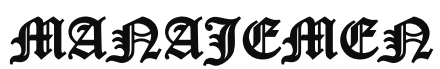

P-ISSN 2615-6849, E-ISSN 2716-070X

Jurnal ABDIMAS Vol. 2,No.3, Agustus 2021,Hal(54-61)

@ Prodi Manajemen Fakultas Ekonomi Universitas Pamulang

Email: abdimasjurnal.unpam@ gmail.com Telp: (021) 741-2566

\begin{tabular}{|l|l|}
\hline barang-barang. \\
Kerajinan tangan bisa \\
terbuat dari barang - \\
barang bekas seperti \\
botol bekas, kardus, \\
dan plastik makanan. \\
Arti yang lain ialah \\
usaha yang berterusan \\
penuh semangat \\
ketekunan, kecekalan, \\
kegigihan, dedikasi \\
dan berdaya maju \\
dalam melakukan \\
sesuatu perkara \\
Kerajinan Tangan \\
bisa disebut juga \\
suatu kegiatan dalam \\
menciptakan suatu \\
bentuk produk yang \\
dominan \\
menggunakan tangan \\
manusia, yang sangat \\
minim dalam \\
penggunaan mesin \\
atau alat otomatis.Hal \\
yang lumrah dalam \\
pembuatan kerajinan \\
tangan adalah \\
mengangkat suatu \\
nilai dari bahan atau \\
barang yang tidak \\
layak pakai (barang \\
bekas), sehingga \\
memiliki fungsi untuk \\
kehidupan dan \\
tentunya bernilai \\
ekonomis. Dalam \\
Kerajinan Tangan, \\
kapasitas produksi \\
terukur dari jumlah \\
orang yang terlibat \\
didalamnya. Selain \\
itu adanya pengaruh \\
ketersedaan bahan \\
baku utama dan \\
pendukung, karena \\
bahan bekas \\
\hline
\end{tabular}

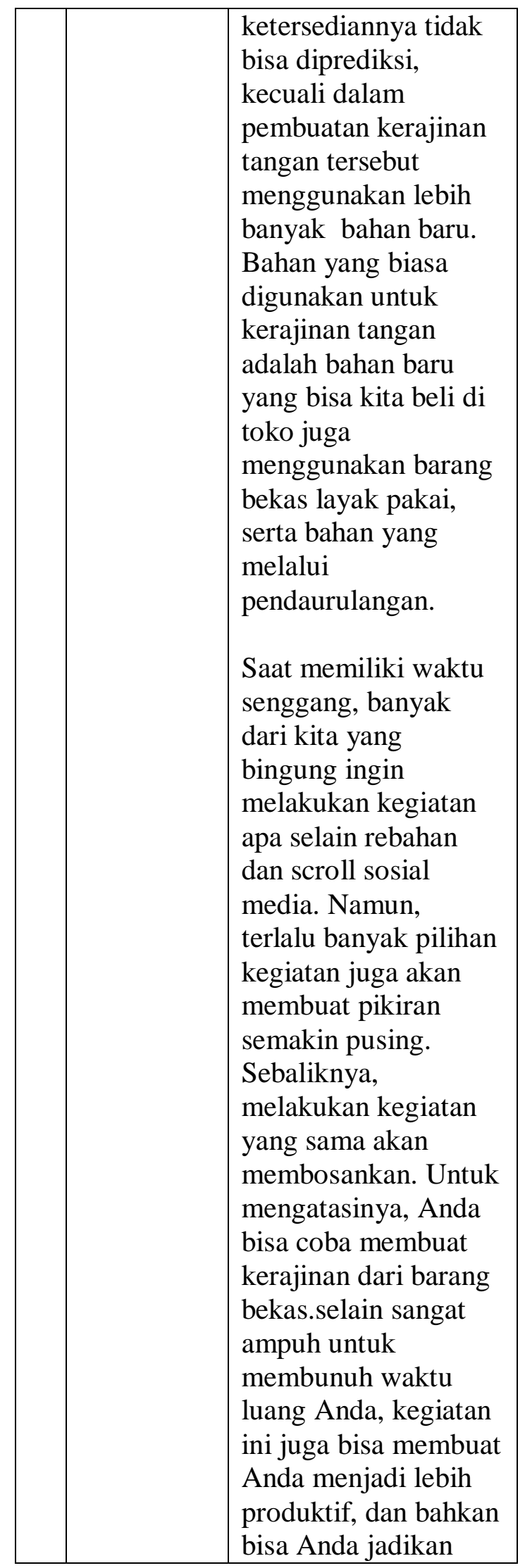


JURNAL ABDIMAS

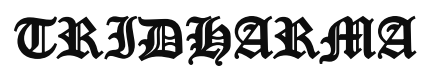
AIA
P-ISSN 2615-6849, E-ISSN 2716-070X

Jurnal ABDIMAS Vol. 2,No.3, Agustus 2021,Hal(54-61)

@ Prodi Manajemen Fakultas Ekonomi Universitas Pamulang

Email: abdimasjurnal.unpam@ gmail.com Telp: (021) 741-2566

\begin{tabular}{|c|c|c|}
\hline & & $\begin{array}{l}\text { sebagai suatu bisnis } \\
\text { yang menarik. }\end{array}$ \\
\hline 2 & $\begin{array}{l}\text { Pengemban } \\
\text { gan } \\
\text { ekonomi } \\
\text { kreatif }\end{array}$ & $\begin{array}{l}\text { Pengembangan } \\
\text { ekonomi kreatif } \\
\text { Indonesia merupakan } \\
\text { wujud optimisme } \\
\text { serata luapan aspirasi } \\
\text { untuk mendukung } \\
\text { mewujudkan visi } \\
\text { Indonesia yaitu } \\
\text { menjadi Negara yang } \\
\text { maju. Didalamnya } \\
\text { terdapat pemikiran, } \\
\text { cita-cita, imajinasi, } \\
\text { dan mimpi untuk } \\
\text { menjadi masyarakat } \\
\text { dengan kualitas hidup } \\
\text { yang tinggi, sejahtera, } \\
\text { dan kreatif. Ekonomi } \\
\text { kreatif menjadikan } \\
\text { sumber daya manusia } \\
\text { sebagai modal utama } \\
\text { dalam sebuah } \\
\text { pengembangan yang } \\
\text { berawal dari gagasan, } \\
\text { ide dan pemikiran. Ke } \\
\text { depannya, diharapkan } \\
\text { SDM ini mampu } \\
\text { menjadikan barang } \\
\text { yang bernilai rendah } \\
\text { menjadi barang yang } \\
\text { bernilai tinggi dan } \\
\text { berdaya jual. Seperti } \\
\text { halnya dengan } \\
\text { pemanfaatan bahan } \\
\text { bahan yang sudah } \\
\text { tidak terpakai/bahan } \\
\text { bekas menjadi barang } \\
\text { bernila tinggi dan } \\
\text { berdaya jual. Dengan } \\
\text { potensi kreatifitas } \\
\text { alami yang } \\
\text { dimilikinya, anak } \\
\text { akan senantiasa } \\
\text { menumbuhkan } \\
\text { aktifitas yang syarat } \\
\text { dengan ide kreatif. Ini }\end{array}$ \\
\hline
\end{tabular}

\begin{tabular}{|c|c|c|}
\hline & & $\begin{array}{l}\text { penting karena rasa } \\
\text { ingin tahu dan } \\
\text { keinginan untuk } \\
\text { mempelajari sesuatu } \\
\text { merupakan karunia } \\
\text { Allah, dan dimiliki } \\
\text { oleh setiap anak. }\end{array}$ \\
\hline 3 & $\begin{array}{l}\text { Inivatif dan } \\
\text { Kreatif }\end{array}$ & $\begin{array}{l}\text { Perkembangan } \\
\text { teknologi saat ini } \\
\text { melahirkan cara baru } \\
\text { dalam menyelesaikan } \\
\text { pekerjaan di berbagai } \\
\text { sektor, seperti } \\
\text { manufaktur, } \\
\text { perbankan, jasa dan } \\
\text { lain sebagainya. } \\
\text { Kondisi ini kemudian } \\
\text { menuntut adanya } \\
\text { sumber daya manusia } \\
\text { (SDM) yang kreatif, } \\
\text { inovatif serta berdaya } \\
\text { saing.Lembaga } \\
\text { pemerintahan tanpa } \\
\text { kreativitas dan } \\
\text { inovasi akan } \\
\text { berakibat organisasi } \\
\text { yang kurang } \\
\text { berkembang dan } \\
\text { kinerjanya akan } \\
\text { selalu menjadi } \\
\text { sorotan masyarakat, } \\
\text { kritikan, dan apatis } \\
\text { bagi institusi itu } \\
\text { sendiri. Oleh karena } \\
\text { itu kreativitas dan } \\
\text { inovasi pada setiap } \\
\text { lembaga pemerintah } \\
\text { yang ingin maju harus } \\
\text { menguatkan di } \\
\text { internalnya terlebih } \\
\text { dahulu, dengan } \\
\text { demikian ketika di } \\
\text { internalnya sudah } \\
\text { kuat dan } \\
\text { menghasilkan produk } \\
\text { organisasi yang siap } \\
\text { dan solid, otomatis }\end{array}$ \\
\hline
\end{tabular}


JURNAL ABDIMAS

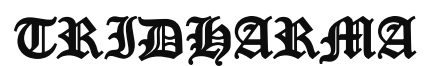
AIA
P-ISSN 2615-6849, E-ISSN 2716-070X

Jurnal ABDIMAS Vol. 2,No.3, Agustus 2021,Hal(54-61)

@ Prodi Manajemen Fakultas Ekonomi Universitas Pamulang

Email: abdimasjurnal.unpam@ gmail.com Telp: (021) 741-2566

\begin{tabular}{|l|l|l|}
\hline & $\begin{array}{l}\text { ketika menghadapi } \\
\text { permasalahan } \\
\text { eksternal organisasi } \\
\text { dapat diatasi. }\end{array}$ \\
\hline 4 & $\begin{array}{l}\text { Hal hal } \\
\text { yang perlu } \\
\text { dilakukan } \\
\text { untuk } \\
\text { menjadi diri } \\
\text { yang kreatif }\end{array}$ & $\begin{array}{l}\text { perlu dilakukan untuk } \\
\text { menjadi diri yang } \\
\text { kreatif dan inovatif, } \\
\text { antara lain dengan } \\
\text { membuat ide-ide baru } \\
\text { sehingga dengan } \\
\text { memiliki ide-ide yang } \\
\text { kreatif, maka akan } \\
\text { tercipta program baru } \\
\text { yang lebih inovatif, } \\
\text { melawan ketakutan } \\
\text { dalam melakukan } \\
\text { perubahan dan tidak } \\
\text { takut akan kegagalan, } \\
\text { memiliki motivasi } \\
\text { diri yang kuat } \\
\text { sehingga ide yang } \\
\text { diciptakan dapat } \\
\text { diaplikasikan dengan } \\
\text { mudah dan tidak akan } \\
\text { menyerah dalam } \\
\text { menghadapi } \\
\text { kegagalan, menerima } \\
\text { pendapat pihak lain } \\
\text { terhadap ide yang } \\
\text { akan direalisasikan, } \\
\text { serta memperluas } \\
\text { wawasan dengan } \\
\text { membaca sehingga } \\
\text { mendapat } \\
\text { pengetahuan untuk } \\
\text { menciptakan ide-ide } \\
\text { baru. Dengan menjadi } \\
\text { pribadi yang kreatif } \\
\text { dan inovatif, maka } \\
\text { juga akan mendorong } \\
\text { pada peningkatan } \\
\text { produktivitas. Di } \\
\text { mana pribadi yang } \\
\text { produktif memiliki } \\
\text { kemauan untuk } \\
\text { menghasilkan sesuatu }\end{array}$ \\
\hline
\end{tabular}

\begin{tabular}{|c|c|c|}
\hline & & $\begin{array}{l}\text { yang lebih banyak } \\
\text { dari biasanya. Hal ini } \\
\text { akan sangat } \\
\text { membawa dampak } \\
\text { baik kepada sebuah } \\
\text { organisasi. Dengan } \\
\text { menjadi sumber daya } \\
\text { manusia yang kreatif, } \\
\text { inovatif, dan } \\
\text { produktif, maka } \\
\text { secara otomatis juga } \\
\text { akan membawa } \\
\text { organisasi pada } \\
\text { pencapaian tujuan } \\
\text { yang telah ditetapkan } \\
\text { dengan maksimal. }\end{array}$ \\
\hline 5 & $\begin{array}{l}\text { Cara untuk } \\
\text { mengemban } \\
\text { gkan } \\
\text { kreatifitas }\end{array}$ & $\begin{array}{l}\text { beberapa cara yang } \\
\text { dapat dilakukan untuk } \\
\text { mengembangkan } \\
\text { kreativitas: } \\
\text { 1. Amatilah } \\
\text { sesuatu yang } \\
\text { dikenal. } \\
\text { Tujuannya } \\
\text { adalah untuk } \\
\text { melatih dan } \\
\text { mempertajam } \\
\text { ingatan Anda. } \\
\text { 2. Membangun } \\
\text { kreatifitas } \\
\text { berarti } \\
\text { mempertajam } \\
\text { pikiran, dan } \\
\text { itu berarti juga } \\
\text { meningkatkan } \\
\text { kepekaan } \\
\text { pengindraan } \\
\text { pada diri kita. } \\
\text { Jangan } \\
\text { menunda } \\
\text { pekerjaan. } \\
\text { Dengan } \\
\text { adanya } \\
\text { persiapan } \\
\text { waktu yang } \\
\text { baik selama }\end{array}$ \\
\hline
\end{tabular}


JURNAL ABDIMAS

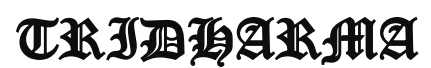

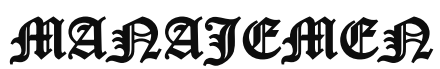

P-ISSN 2615-6849, E-ISSN 2716-070X

Jurnal ABDIMAS Vol. 2,No.3, Agustus 2021,Hal(54-61)

@ Prodi Manajemen Fakultas Ekonomi Universitas Pamulang

Email: abdimasjurnal.unpam@ gmail.com Telp: (021) 741-2566

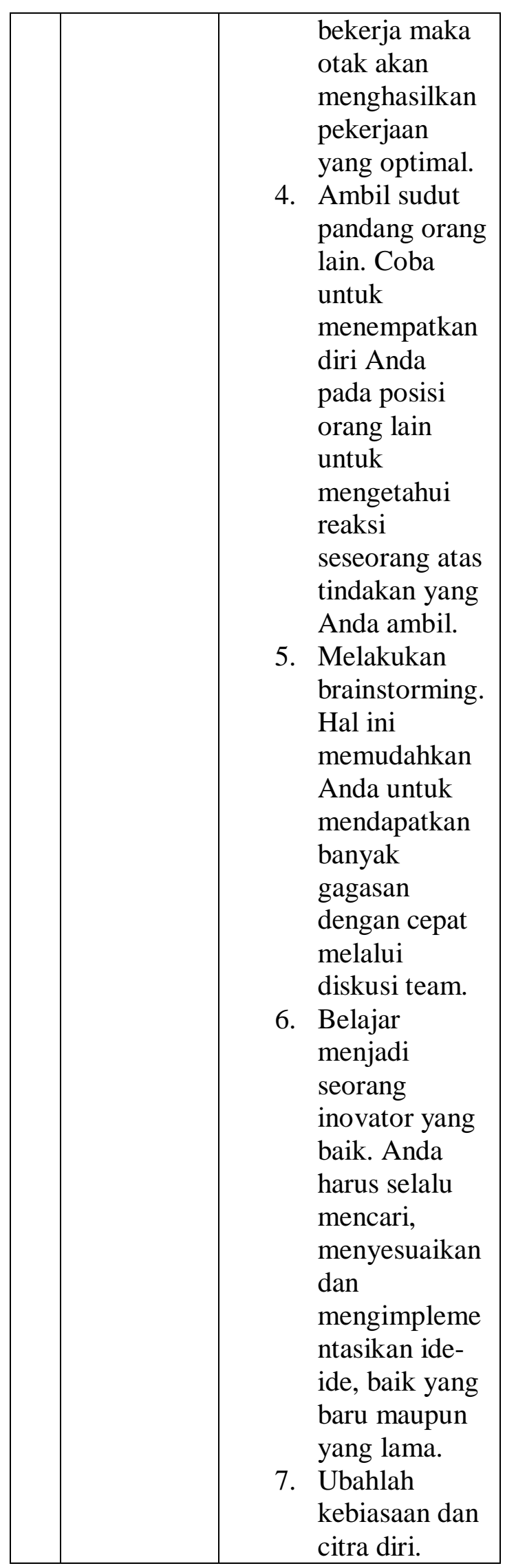

\begin{tabular}{|l|l|}
\hline & Jadilah orang \\
yang \\
progresif, \\
kembangkanla \\
h atribut- \\
atribut dan \\
motivasi yang \\
di butuhkan. \\
\hline
\end{tabular}

\section{Kesimpulan}

Pelaksanaan pengabdian kepada masyarakat oleh tim PKM Mahasiswa/i PRODI Akuntansi sangat membantu anak untuk terus ber inovatif dan kreatif secara pesat , dari kurangnya pemahaman mengenai pemanfaatan bahan bekas, saat ini peserta sudah memahami cara bagaimana memanfaatkan bahan bekas menjadi sebuah kerajinan yang bernilai tinggi dan bernilai jual. sehingga dapat menunjang perkembangan dan kemajuan daya fikir anak untuk lebih kreatif.

Dengan menjadi pribadi yang kreatif dan inovatif, maka juga akan mendorong pada peningkatan produktivitas. Di mana pribadi yang produktif memiliki kemauan untuk menghasilkan sesuatu yang lebih banyak dari biasanya. Hal ini akan sangat membawa dampak baik kepada sebuah organisasi. Dengan menjadi sumber daya manusia yang kreatif, inovatif, dan produktif, maka secara otomatis juga akan membawa organisasi pada pencapaian tujuan yang telah ditetapkan dengan maksimal

\section{DAFTAR PUSTAKA}

Handayani, Novi. Dkk. 2018. Pengaruh Influencer Marketing Sebagai strategi Pemasaran digital era Modern (Sebuah Strategi Literatur). Jurnal EKSEKUTIF Volume 15, no 1 Juni 2018. 


\section{JURNAL ABDIMAS

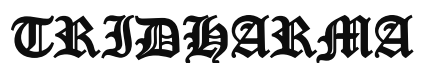

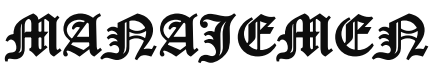

P-ISSN 2615-6849, E-ISSN 2716-070X

Jurnal ABDIMAS Vol. 2,No.3, Agustus 2021,Hal(54-61)

@ Prodi Manajemen Fakultas Ekonomi Universitas Pamulang

Email: abdimasjurnal.unpam@gmail.com Telp: (021) 741-2566
Khasali, R. (2018). Strawberry Generation. Jakarta: Mizan.

Oktavianita, Bella. Dkk. 2020. Pengembangan Ekonomi Desa Padanaan dengan Wirausaha Keripik Kulit pisang di Kabupaten Sumedang. Jurnal Pusat Inovasi Masyarakat ISSN 2721897X: Juni 2020, Vol 2(4) 2020:690695.

Pasaribu, V. L. D., Agrasadya, A., Shabrina, N., \& Krisnaldy, K. (2020). Menjadi Enterpreneur Muda Yang Memiliki Jiwa Leadership Untuk Menghadapi Masa Depan. Abdi Laksana: Jurnal Pengabdian Kepada Masyarakat, 1(1).

Pasaribu, V. L. D., Susanti, F., \& Hartuti, E. T. K. (2019). Memotivasi Siswa dan Siswi SMK Letris Indonesia di Dalam Menentukan Pilihan Untuk Melanjutkan Pendidikan Atau Bekerja Setelah Lulus Sekolah. Jurnal Pengabdian Dharma Laksana, 1(2), 161-172.

Pasaribu, V. L. D., Sulaiman, S., Sutiman, S., Thaharudin, T., \& Purnomo, B. Y. (2020). Pengenalan Letak Posyandu Terdekat Dikelurahan Pisangan Dengan Manajemen Pemasaran Revolusi 4.0 Untuk Meningkatkan Pengetahuan Masyarakat Letak Dan Fungsi Posyandu Terdekat Pada Kelurahan Pisangan. Dedikasi Pkm, 1(1), 105-110.

Pasaribu, V. L. D., Oktrima, B., Prabowo, B., Arianto, N., \& Haryoko, U. B. (2020). Progam Pendampingan Dan Penyelenggaraan Pendidikan Anak Pada Usia Dini Terhadap Prestasi Belajar Dilingkungan Rt 020 Rw 009. Kel Giri Peni. Kec Wates. Yogyakarta. Jurnal Lokabmas Kreatif, 1(1), 71-75.

Pasaribu, V. L. D., Jannah, M., Fazar, M., Putra, S. P., Monalisa, M., \& Sofa, M. (2021).

MENINGKATKAN PRODUKTIVITAS USAHA DIMASA PANDEMI PADA IBU PKK RT 004/003 KELURAHAN SAWAH BARU CIPUTAT,
TANGERANG SELATAN. $A b d i$ Laksana: Jurnal Pengabdian Kepada Masyarakat, 2(2), 295-301.

Pasaribu, V. L. D., Yuniati, H. L., Pranata, R., Sembayu, R., Purba, S. M., \& Nurbayani, T. T. A. (2021). MANAJEMEN KEUANGAN UNTUK MENGHADAPI DAN BERTAHAN DI ERA COVID 19. Jurnal Abdimas Tri Dharma Manajemen, 2(2), 12-18.

Pasaribu, V. L. D., Dwiyatni, A., Sabina, C., Ridwan, M., Gunawan, D. D., \& Noviani, B. C. (2021). EVALUASI PENERAPAN 3M DIMASA PANDEMIC COVID 19. Jurnal Abdimas Tri Dharma Manajemen, 2(2), 54-60.

Pasaribu, V. L. D., Syafei, A. N., Farhan, A., Aufaizah, A., Irani, C., \& Firtiayani, S. R. (2021). PENGARUH DISPLIN PROTOKOL KESEHATAN TERHADAP PENCEGAHAN PENULARAN VIRUS COVID19. Jurnal Abdimas Tri Dharma Manajemen, 2(2), 91-98.

Pasaribu, V. L. D., Septiani, F., Rahayu, S., Lismiatun, L., Arief, M., Juanda, A., ... \& Rahim, R. (2021). Forecast Analysis of Gross Regional Domestic Product based on the Linear Regression Algorithm Technique.

Priadi, A., Pasaribu, V. L. D., Virby, S., Sairin, S., \& Wardani, W. G. (2020). Penguatan Ekonomi Kreatif Berbasis Sumber Daya Desa Dikelurahan Rempoa. Abdi Laksana: Jurnal Pengabdian Kepada Masyarakat, 1(3), 356-35

Pradiani, Theresia. 2017. Pengaruh Sistem Pemasaran Digital Marketing Terhadap Peningkatan Volume Penjualan Hasil Industri Rumahan. JIBEKA Volume 11 Nomor 2 Februari 2017 : 46-53.

Prasetyo, Hoedi dan Sutopo, Wahyudi.2018.Industri 4.0: Telaah klasifikasi aspek dan arah perkembangan riset. Jurnal Teknik 


\section{JURNAL ABDIMAS

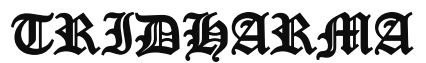

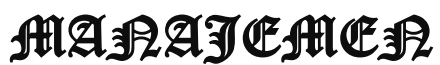

P-ISSN 2615-6849, E-ISSN 2716-070X

Jurnal ABDIMAS Vol. 2,No.3, Agustus 2021,Hal(54-61)

@ Prodi Manajemen Fakultas Ekonomi Universitas Pamulang

Email: abdimasjurnal.unpam@ gmail.com Telp: (021) 741-2566
Insdustri (J@TI). Volume 13.No.1. Halaman 17-18.

Rezasyah, Teuku. Ivan dan Affabile.2018. Kesiapan Siswa SMK dalamRevolusi Industri 4.0. Jurnal Pengabdian Kepada Masyarakat. Kumawula, Vol. 1, No.2, Agustus 2018, Hal $114-119$.

Shwab, K. (2016). The Fourth Industrial Revolution. New York: Crown Business.

\section{Web Site}

[1] https://webcache.googleusercontent.com/se arch?q=cache:1_3cl_xWT2gJ:https://media.ne liti.com/media/publications/182418-ID-peranekonomi-kreatif-terhadap-

pengemban $\cdot$ pdf $+\& c d=3 \& h l=i d \& c t=c l n k \& g l=i$ d\&client=firefox-b-d, diakses pada 27 Mei 2021

[2]https://www.kompasiana.com/t4len_ti4n/5 50066678133116619fa76ff/apakahkreatifitas-itu-dan-bagaimana-orang-yangkreatif, diakses pada 27 Mei 2021

[3]http://alchemy.co.id/pr-agency/caramengembangkan-kreativitas-diri/, diakses pada 27 Mei 2021

[4]https://www.detik.com/edu/detikpedia/d5484593/pengertian-kerajinan-tujuan-jenisdan-contohnya,diakses pada 10 Maret 2021

[5]https://www.djkn.kemenkeu.go.id/kanw il-jateng/baca-artikel/12739/SDM-yangKreatif-Inovatif-danProduktif.html,diakses pada 27 Mei 2021

\section{FOTO DOKUMENTASI}
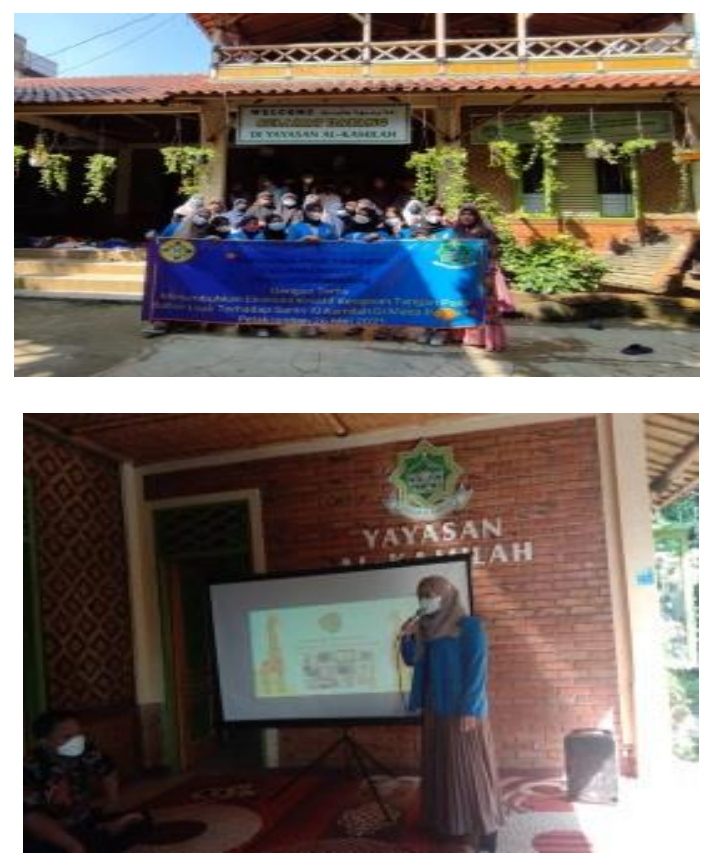